\title{
Evaluation of Serum Endothelin-1 (ET-1) and Nitric Oxide (NO) Levels in Unconjugated Hyperbilirubinemic Neonates
}

\author{
Hosny M. A. El-Masry ${ }^{1}$, Alaaeldin A. Hassan', Alaa M. Hashim², \\ Mohammed Abo-Alwafa Aladawy ${ }^{1}$, Asmaa Ahmed Alameldin Abdelwahab*1 \\ Departments of ${ }^{1}$ Pediatrics and ${ }^{2}$ Clinical Pathology, Faculty of Medicine, Al-Azhar University, Assiut, Egypt \\ *Corresponding author: Asmaa A. Alm El-Dien Abd El-Wahab, Mobile: (+20) 01000541589,
}

E-Mail: amata2008@yahoo.com

\begin{abstract}
Background: Neonatal hyperbilirubinemia is the most common cause of admission in NICU. Phototherapy is the golden standerd therapy long time ago, which shows efficacy and safety but its side effects should be studied in depth. Both endotheline 1 (ET-1) and nitric Oxide (NO) are potent vasoconstrictor and vasodilator respectively and they are affected by phototherapy.

Objectives: This study aimed to investigate the impact of phototherapy on the level of ET-1 and NO in fullterm and preterm as well as studying their effect on hemodynamic stability in treated newborns.

Subjects and Methods: This study included 120 newborn infants who were classified into two groups. 60 patients (30 term infants and 30 preterm infants $<37$ weeks and $>30$ weeks) with unconjugated hyperbilirubinemia indicated for phototherapy and not indicated for exchange transfusion and the onset of jaundice from $2^{\text {nd }}$ to $4^{\text {th }}$ day. In addition, to 60 apparently healthy newborns as control group with matched age, sex, weight and gestational age. Results: There was significant increase in both endothelin-1 and nitric oxide in both fullterm and preterm groups after phototherapy. For fullterm and preterm groups, ET-1 levels significantly increased after 12 hour and 24 hour phototherapy ( $\mathrm{p}$-value $=0.048$ and 0.013 respectively) for fullterm ( $\mathrm{p}$-value $=0.046$ and 0.028 respectively) for preterm. Nitric oxide levels among fullterm and preterm groups significantly increased after 12 hour and 24 hour phototherapy ( $\mathrm{p}$-value $=0.042$ and 0.012 respectively) for fullterm ( $\mathrm{p}$ value $=0.048$ and 0.012 respectively) for preterm. The means heart rate changes among fullterm and preterm groups were significantly increased. However, mean arterial blood pressure among full term and preterm groups was significantly decrease after 24 hours of phototherapy. There was a positive correlation between serum levels of ET-1 and NO and heart rate after phototherapy among term and preterm neonats. A negative correlation was found between mean BP and serum levels of NO and a positive correlation between serum levels of ET-1 and mean BP after phototherapy among term and preterm neonates.

Conclusion: There was significant increase in both endothelin-1 and nitric oxide in both fullterm and preterm groups after treatment with photo-therapy. In addition, a significant increase in mean heart rate and a significant decrease in mean blood pressure among preterm and fullterm groups befor and after phototherapy and before phototherapy versus controls.
\end{abstract}

Keywords: Neonatal hyperbilirubinemia, Phototherapy, Endothelin-1, Nitric Oxide.

\section{INTRODUCTION}

Neonatal jaundice is defined as yellowish discoloration of the skin, sclera of eyeball, and mucous membranes due to deposition of bilirubin in these tissues. Depending upon the cause, jaundice may be present at birth or any time during the neonatal period. Jaundice due to either indirect (unconjugated) or direct (conjugated) bilirubin within the first 24 hours of life should be taken seriously ${ }^{(1)}$. Phototherapy has remained the standard of care for the treatment of hyperbilirubinemia in infants for four decades. Efficient phototherapy rapidly reduces serum bilirubin concentration ${ }^{(2)}$ and it is generally regarded as a safe method.

The reported side effects have been subjected to extensive and controversial debate and include rashes, loose green stools, water loss, oxidative injury, dehydration and ocular hazards ${ }^{(3)}$. One of the most noticeable clinical complication of phototherapy is "bronze baby syndrome", a greyishbrown discoloration of the skin that occurs exclusively in infants with cholestatic jaundice. Phototherapy treatment has been suggested to alter heart function by increasing the heart rate and diminishing the variabilities of heart rate and cardiac output while affecting blood vessel function by diminishing the mean arterial blood pressure and increasing peripheral blood flow. After phototherapy treatment, closure of PDA may be affected via alteration of the fluid homeostasis and cardiovascular function ${ }^{(4)}$.

Effect of phototherapy on the autonomic nervous system modulatin of heart rate in term neonates are apparent as significant diminution in heart rate variability was documented during phototherapy, a phenomenon assumed to be centrally mediated. The reasons for this decrease are yet unknown ${ }^{(5)}$. 
NO has been noted to relax the smooth muscle and walls of arterioles. The complex endothelial cells lining the blood vessels release a puff of NO at each systole, which gets diffused into the underlying smooth muscle cell, and thus permits the surge of blood to pass through easily ${ }^{(6)}$.

The pharmacological action of ET-1 is very unusual compared with other vasoactive mediators such as angiotensin-II (ANG-II). It remains the most powerful constrictor of human vessels discovered with a remarkably long-lasting action. ET-1 and NO are natural counterparts in vascular function, and it is becoming increasingly clear that an imbalance between these two mediators is a characteristic of endothelial dysfunction and is important in the progression of vascular disease ${ }^{(7)}$.

\section{AIM OF THE STUDY}

We aimed at this study to evaluate the effect of phototherapy used for treatment of neonatal hyperbilirubinemia on the blood levels of endothelin1 (ET-1) and nitric oxide (NO) and their hemodynamic effects on both full term and preterm neonates.

\section{SUBJECTS AND METHODS}

This study included 120 newborn infants who were classified into two groups. 60 patients (30 term infants and 30 preterm infants $<37$ weeks and $>30$ weeks) in addition to 60 apparently healthy newborns as control group with matched age, sex and weight for gestational age. Patients and controls were recruited from NICU, Al-Azhar Assiut Univeristy Hospital. The present work was conducted from January 2018 till the end of June 2020.

Inclusion criteria: Full term and preterm unconjugated hyperbilirubinemic newborns indicated for phototherapy and not indicated for exchange transfusion. Onset of jaundice from $2^{\text {nd }}$ to $4^{\text {th }}$ day.

Exclusion criteria: Preterm less than 30 weeks. Onset of jaundice before 2 days or after 4 days. Unconjugated hyperbilirubinemic newborns with infection, metabolic or congenital malformation or other systemic diseases and an infant with cephalhematoma.

All patients and controls, included in the study were subjected to the followings: Maternal obstetric or medical history. Gestational age, birth order, and family history of neonatal jaundice. Clinical examination including estimation of gestational age using (Ballard score), neonatal reflexes and anthropometric measurements. Vital signs: heart rate $(\mathrm{HR})$, respiratory rate (RR), mean arterial blood pressure (MABP) and body temperature. Colors: pallor, jaundice and cyanosis. Thorough systemic examination.

Investigations: Blood samples: $5 \mathrm{ml}$ (divided into 2 tubes; one with EDTA and other tube with clotted sample). The following investigations were done for all infants before phototherapy and for controls: CBC and reticulocytes, ESR CRP, blood clutures, blood group for mothers and their infants, total and conjugated serum bilirubin level, urine analysis and cultures, serum ET-1 and serum NO levels. Continous 24-hour phototherapy (mixed blue and white lights; Iskra HKG, Yugoslavia) was administered to newborns with documented hyperbilirubinemia with a wavelength of $430 \mathrm{~nm}$. The light was placed $35-40 \mathrm{~cm}$ above the neonates who were completely exposed except for genitalia and eyes, and the vertical illumination area was $30 \times 60 \mathrm{~cm}^{(8)}$. Then re-assay of ET-1 and NO 12hours 24-hours after phototherapy.

\section{Ethicial considerations:}

Verbal consent was taken from parents before including them and their newborns in this study. Aims of the study and any possible risks will be discussed with parents. Privacy of the collected data was assured. An approval of the study was obtained from Al- Azhar University academic and ethical committee.

\section{Statistical Analysis}

The data were tested for normality using the Anderson-Darling test and for homogeneity variances prior to further statistical analysis. Categorical variables were described by number and percent. Continuous variables were described by mean and standard deviation. Chi-square test and fisher exact test were used to compare between categorical variables. While, Independent-Samples T test and ANOVA were used to compare between continuous variables. We used Pearson and Spearman correlation to detect the association between variables. All analyses were performed with the IBM SPSS 20.0 software. P-value $\leq 0.05$ was considered statistically significant. 


\section{RESULTS}

Table (1): Blood ET-1 and NO levels among fullterm unconjugated hyperbilirubinemic newborns versus full term controls

\begin{tabular}{|c|c|c|c|}
\hline \multirow[b]{2}{*}{ Groups } & \multirow[t]{2}{*}{ Variables } & \multirow{2}{*}{$\begin{array}{l}\text { Endothelin } \\
\text { Mean } \pm \text { SD }\end{array}$} & \multirow{2}{*}{$\begin{array}{l}\text { Nitric oxide } \\
\text { Mean } \pm \text { SD }\end{array}$} \\
\hline & & & \\
\hline \multirow{3}{*}{$\begin{array}{l}\text { Full term unconjugated } \\
\text { hyperbilirubinemic } \\
\text { newborns }\end{array}$} & Before phototherapy & $53.20 \pm 6.14$ & $54.56 \pm 6.95$ \\
\hline & After 12 hours & $55.94 \pm 6.30$ & $59.77 \pm 5.03$ \\
\hline & After 24 hours & $65.42 \pm 6.36$ & $62.23 \pm 5.26$ \\
\hline \multicolumn{2}{|l|}{ Full term controls } & $39.27 \pm 6.37$ & $33.99 \pm 4.56$ \\
\hline \multicolumn{2}{|l|}{ P-value ${ }^{1}$} & $0.048^{*}$ & $0.042 *$ \\
\hline \multicolumn{2}{|l|}{ P-value ${ }^{2}$} & $0.013^{*}$ & $0.012^{*}$ \\
\hline \multicolumn{2}{|l|}{ P-value ${ }^{3}$} & $0.016^{*}$ & $0.045^{*}$ \\
\hline \multicolumn{2}{|l|}{ P-value ${ }^{4}$} & $0.005^{*}$ & $0.003^{*}$ \\
\hline \multicolumn{2}{|l|}{ P-value ${ }^{5}$} & $0.004 *$ & $0.006^{*}$ \\
\hline \multicolumn{2}{|l|}{ P-value ${ }^{6}$} & $0.002 *$ & $0.004 *$ \\
\hline
\end{tabular}

1: Comparison between before phototherapy and after 12 hours.

2: Comparison between before phototherapy and after 24 hours.

3: Comparison between after 12 hours and after 24 hours.

4: Comparison between before phototherapy and control.

5: Comparison between after 12 hours and control.

6: Comparison between after 24 hours and control.

Table (1) showed statistically significant differences between blood levels of both ET-1 and NO before, 12 hours and 24 hours after phototherapy in fullterm unconjugated hyperbilirubinemic newborns and between their levels in patients and controls.

Table (2): Blood ET-1 and NO levels among preterm unconjugated hyperbilirubinemic newborns and preterm controls

\begin{tabular}{|c|c|c|c|}
\hline \multirow[b]{2}{*}{ Groups } & \multirow[t]{2}{*}{ Variables } & \multirow{2}{*}{$\begin{array}{l}\text { Endothelin } \\
\text { Mean } \pm \text { SD }\end{array}$} & \multirow{2}{*}{$\begin{array}{l}\text { Nitric oxide } \\
\text { Mean } \pm \text { SD }\end{array}$} \\
\hline & & & \\
\hline \multirow{3}{*}{$\begin{array}{l}\text { Preterm unconjugated } \\
\text { hyperbilirubinemic } \\
\text { newborns }\end{array}$} & Before phototherapy & $47.75 \pm 9.97$ & $41.84 \pm 7.08$ \\
\hline & After 12 hours & $51.13 \pm 8.84$ & $45.33 \pm 6.51$ \\
\hline & After 24 hours & $55.31 \pm 9.30$ & $73.13 \pm 6.36$ \\
\hline \multicolumn{2}{|l|}{ Preterm controls } & $31.24 \pm 5.16$ & $25.62 \pm 4.84$ \\
\hline \multicolumn{2}{|l|}{ P-value ${ }^{1}$} & $0.046^{*}$ & $0.048^{*}$ \\
\hline \multicolumn{2}{|l|}{ P-value ${ }^{2}$} & $0.028^{*}$ & $0.012 *$ \\
\hline \multicolumn{2}{|l|}{ P-value ${ }^{3}$} & $0.045^{*}$ & $0.014 *$ \\
\hline \multicolumn{2}{|l|}{ P-value ${ }^{4}$} & $0.004 *$ & $0.002 *$ \\
\hline \multicolumn{2}{|l|}{ P-value ${ }^{5}$} & $0.006^{*}$ & $0.006^{*}$ \\
\hline \multicolumn{2}{|l|}{ P-value ${ }^{6}$} & $0.002 *$ & $0.001 *$ \\
\hline
\end{tabular}

\footnotetext{
1: Comparison between before phototherapy and after 12 hours.

2: Comparison between before phototherapy and after 24 hours.

3: Comparison between After 12 hours and After 24 hours.

4: Comparison between before phototherapy and control.

5: Comparison between After 12 hours and Control.

6: Comparison between after 24 hours and control.

$P$ value $\leq 0.05$ : statistically significant.
}

Table (2) showed statistically significant differences between blood levels of both ET-1 and NO before, 12 hours and 24 hours after phototherapy in preterm unconjugated hyperbilirubinemic newborns and between their levels in patients and controls. 
Table (3): Heart rate and MABP levels among full-term unconjugated hyperbilirubinemic newborns and fullterm controls.

\begin{tabular}{|c|c|c|c|c|c|c|}
\hline \multirow[t]{3}{*}{$\begin{array}{ll}\text { Variables } & \text { Groups } \\
\end{array}$} & \multicolumn{2}{|c|}{$\begin{array}{c}\text { Full-term unconjugated } \\
\text { hyperbilirubinemic newborns }\end{array}$} & \multirow[t]{2}{*}{$\begin{array}{l}\text { Full term } \\
\text { controls }\end{array}$} & \multirow[t]{3}{*}{$\begin{array}{c}\text { P- } \\
\text { value }^{1}\end{array}$} & \multirow[t]{3}{*}{$\begin{array}{c}\text { P- } \\
\text { value }^{2}\end{array}$} & \multirow[t]{3}{*}{$\begin{array}{c}\text { P- } \\
\text { value }^{3}\end{array}$} \\
\hline & $\begin{array}{c}\text { Before } \\
\text { phototherapy }\end{array}$ & $\begin{array}{c}\text { After } \\
24 \text { hours }\end{array}$ & & & & \\
\hline & Mean \pm SD & Mean \pm SD & Mean \pm SD & & & \\
\hline Heart rate (beat/ min) & $134.50 \pm 4.73$ & $135.73 \pm 3.96$ & $138.20 \pm 8.28$ & $0.05^{*}$ & $0.038^{*}$ & $0.031 *$ \\
\hline Mean ABP (mmHg) & $60.30 \pm 4.42$ & $57.23 \pm 4.61$ & $56.37 \pm 3.90$ & $0.047 *$ & $0.046^{*}$ & 0.435 \\
\hline
\end{tabular}

1: Comparison between before phototherapy and after 24 hour.

2: Comparison between before phototherapy and control.

3: Comparison between after 24 hours and control. ABP: Arterial blood pressure. P value $\leq 0.05$ : statistically significant.

Table (3) showed statistically significant differences between mean heart rate in full term unconjugated hyperbilirubinemic newborns before and 24 hours after phototherapy and between their levels in patients and controls. In addition, it showed statistically significant differences between MABP levels in full term unconjugated hyperbilirubinemic newborns before and 24hours after phototherapy and between their levels in patients and controls except between their levels after 24 hours and control.

Table (4): Heart rate and MABP levels among preterm unconjugated hyperbilirubinemic newborns and preterm controls.

\begin{tabular}{|c|c|c|c|c|c|c|}
\hline \multirow{3}{*}{ Variables } & \multicolumn{2}{|c|}{$\begin{array}{c}\text { Preterm unconjugated } \\
\text { hyperbilirubinemic newborns }\end{array}$} & \multirow{2}{*}{$\begin{array}{l}\text { Preterm } \\
\text { controls }\end{array}$} & \multirow{3}{*}{ P-value ${ }^{1}$} & \multirow{3}{*}{ P-value ${ }^{2}$} & \multirow{3}{*}{ P-value ${ }^{3}$} \\
\hline & $\begin{array}{c}\text { Before } \\
\text { phototherapy }\end{array}$ & $\begin{array}{c}\text { After } \\
24 \text { hours }\end{array}$ & & & & \\
\hline & Mean \pm SD & Mean \pm SD & Mean \pm SD & & & \\
\hline Heart rate (beat /min) & $137.07 \pm 5.89$ & $140.80 \pm 5.25$ & $134.47 \pm 7.77$ & $0.01 *$ & 0.140 & $0.012 *$ \\
\hline Mean ABP (mmHg) & $58.70 \pm 3.82$ & $56.37 \pm 3.55$ & $53.73 \pm 4.38$ & $0.05^{*}$ & $0.045^{*}$ & $0.015^{*}$ \\
\hline
\end{tabular}

1: Comparison between before phototherapy and after 24 hours.

2: Comparison between before phototherapy and control.

3: Comparison between after 24 hours and control. ABP: Arterial blood pressure. $\quad \mathrm{P}$ value $\leq 0.05$ : statistically significant.

Table (4) showed statistically significant differences between mean heart rate in full term unconjugated hyperbilirubinemic newborns before and 24 hours after phototherapy ecxept between their levels before phototherapy and controls which is non significant. In addition, it showed statistically significant differences between MABP levels in full term unconjugated hyperbilirubinemic newborns before and 24 hours after phototherapy and between their levels in patients and controls.

Table (5): Blood ET-1 and NO levels among full term and preterm unconjugated hyperbilirubinemic newborns

\begin{tabular}{|c|c|c|c|}
\hline \multirow[b]{2}{*}{ Variables } & $\begin{array}{c}\text { Full term unconjugated } \\
\text { hyperbilirubinemic newborns } \\
(n=30)\end{array}$ & $\begin{array}{c}\text { Preterm unconjugated } \\
\text { hyperbilirubinemic newborns } \\
(n=30)\end{array}$ & \multirow[t]{2}{*}{ P-value } \\
\hline & Mean \pm SD & Mean \pm SD & \\
\hline \multicolumn{4}{|l|}{ Endothelin: (pg / ml) } \\
\hline Before phototherapy & $53.20 \pm 6.14$ & $47.75 \pm 7.97$ & $0.018^{*}$ \\
\hline After 12 hours & $55.94 \pm 6.30$ & $51.13 \pm 8.84$ & $0.018^{*}$ \\
\hline After 24 hours & $65.42 \pm 6.36$ & $55.31 \pm 7.30$ & $0.007 *$ \\
\hline \multicolumn{4}{|l|}{ Nitric oxide: (umol / L) } \\
\hline Before phototherapy & $54.56 \pm 6.95$ & $41.84 \pm 7.08$ & $0.006^{*}$ \\
\hline After 12 hours & $59.77 \pm 5.03$ & $45.33 \pm 6.51$ & $0.024 *$ \\
\hline After 24 hours & $62.23 \pm 5.26$ & $73.13 \pm 6.36$ & $0.008^{*}$ \\
\hline
\end{tabular}

$P$ value $\leq 0.05$ : statistically significant.

Table (5) showed statistically significant differences between blood levels of both ET-1 and NO among full term and preterm unconjugated hyperbilirubinemic newborns. 
Table (6): Mean \pm SD of heart rate and mean arterial blood pressure levels among full term and preterm unconjugated hyperbilirubinemic newborns

\begin{tabular}{|l|c|c|c|}
\hline \multicolumn{1}{|c|}{ Groups } & $\begin{array}{c}\text { Full term unconjugated } \\
\text { hyperbilirubinemic newborns } \\
\text { Variables }\end{array}$ & $\begin{array}{c}\text { Preterm unconjugated } \\
\text { hyperbilirubinemic newborns } \\
(\mathbf{n = 3 0})\end{array}$ & \multirow{2}{*}{ P-value } \\
\cline { 2 - 4 } & Mean \pm SD & Mean \pm SD & \\
\hline Heart rate: (beat / min) & $134.50 \pm 4.73$ & $137.07 \pm 5.89$ & 0.068 \\
\hline Before phototherapy & $135.73 \pm 3.96$ & $140.80 \pm 5.25$ & $0.032^{*}$ \\
\hline After 24 hours & & & 0.139 \\
\hline \hline Mean ABP: $(\mathbf{m m H g )}$ & $60.30 \pm 4.42$ & $58.70 \pm 3.82$ & 0.418 \\
\hline Before phototherapy & $57.23 \pm 4.61$ & $56.37 \pm 3.55$ & \\
\hline After 24 hours & & & \\
\hline
\end{tabular}

$P$ value $\leq 0.05$ : statistically significant

Table (6) showed statistically non significant differences between mean heart rate an MABP levels among full term and preterm unconjugated hyperbilirubinemic newborns except the difference between term and preterm as regard increase in the heart rate after 24 hour phototherapy and controls.

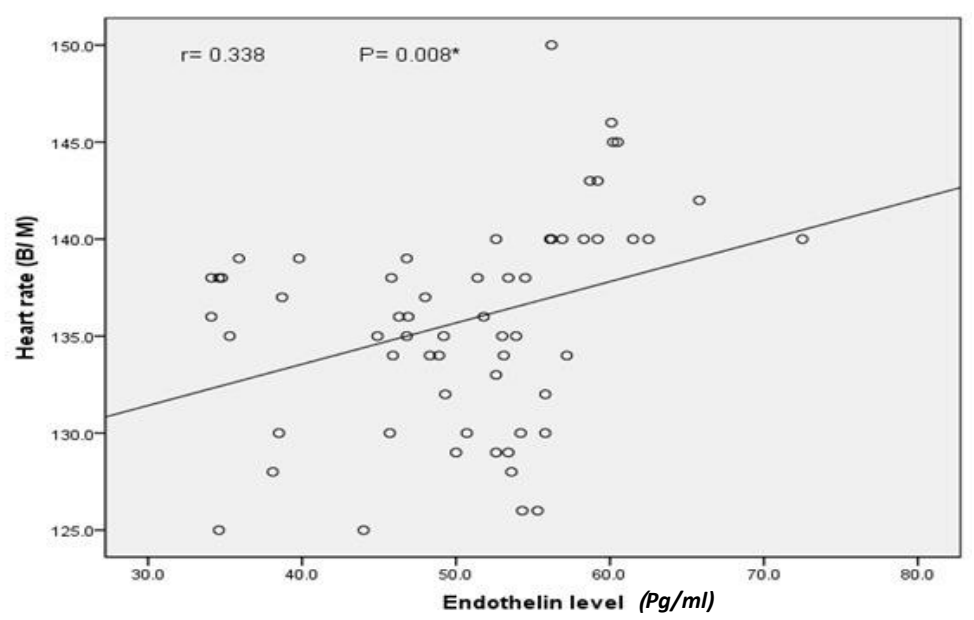

Fig. (1): Correlation coefficient between mean endothelin levels and heart rate in unconjugated hyperbilirubinemic newborns.

Fig. (1) shows positive correlation between mean endothelin levels and heart rate in unconjugated hyperbilirubinemic newborns.

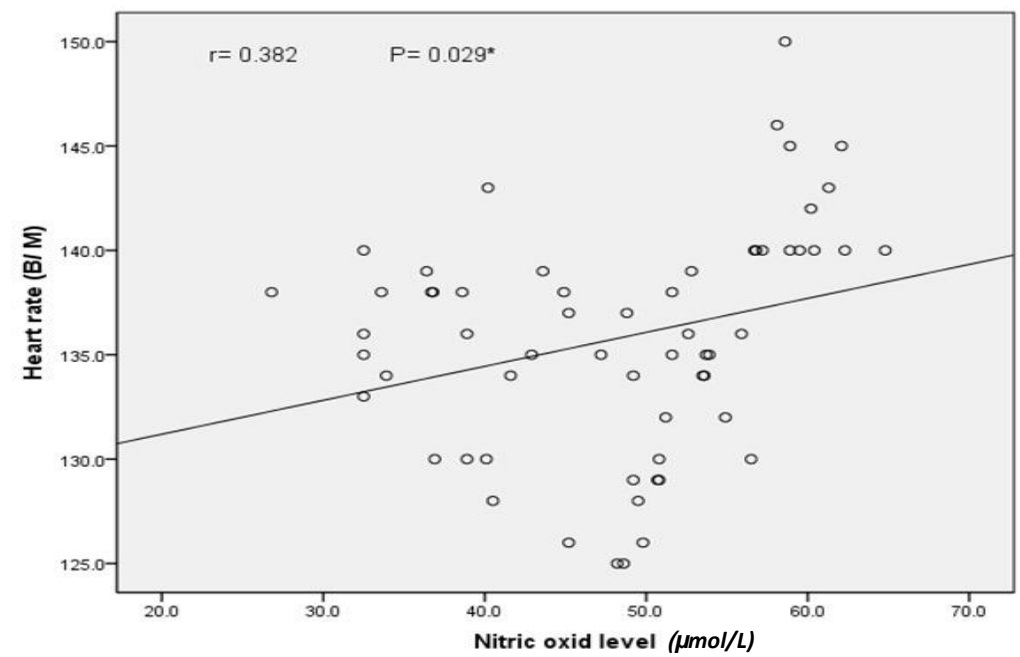

Fig. (2): Correlation coefficient between mean nitric oxide levels and heart rate in unconjugated hyperbilirubinemic newborns.

Fig. (2) shows positive correlation between mean nitric oxide levels and heart rate in unconjugated hyperbilirubinemic newborns 


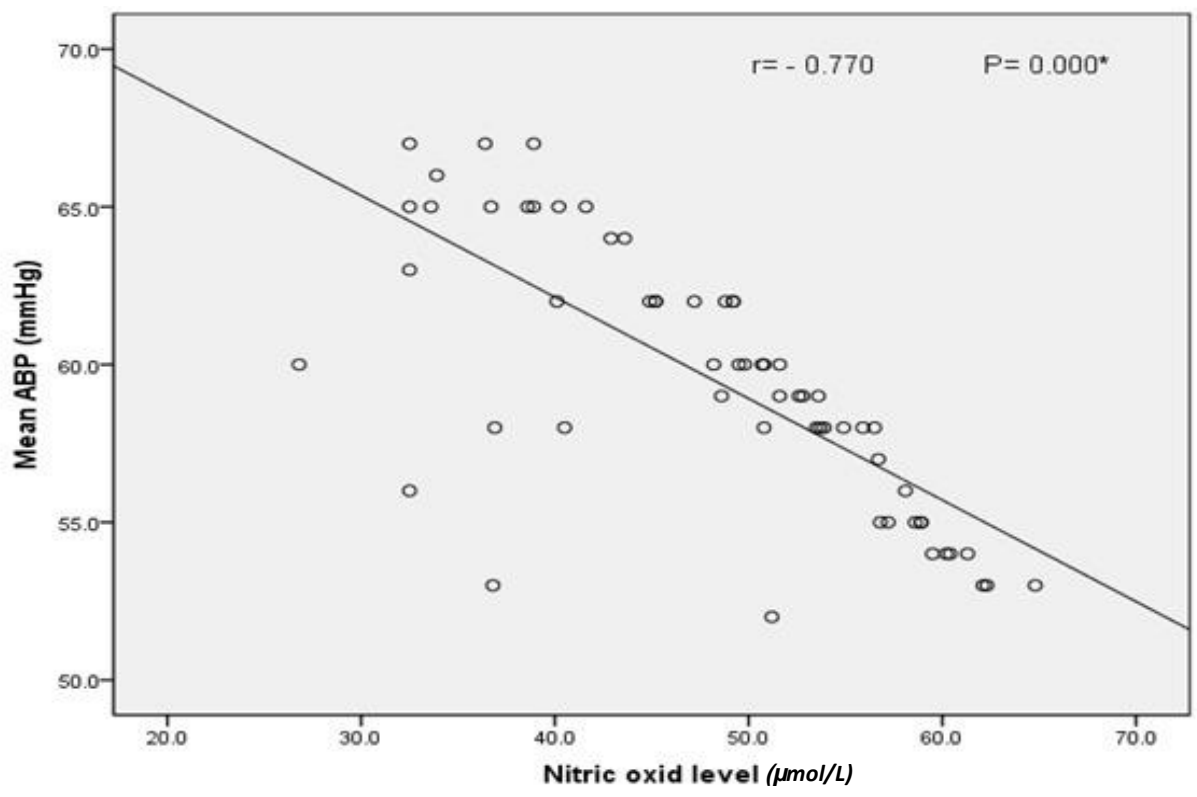

Fig. (3): Correlation coefficient between mean nitric oxide levels amd mean blood pressure in unconjugated hyperbilirubinemic newborns

Fig. (3) shows negative correlation between mean nitric oxide levels amd mean blood pressure in unconjugated hyperbilirubinemic newborns

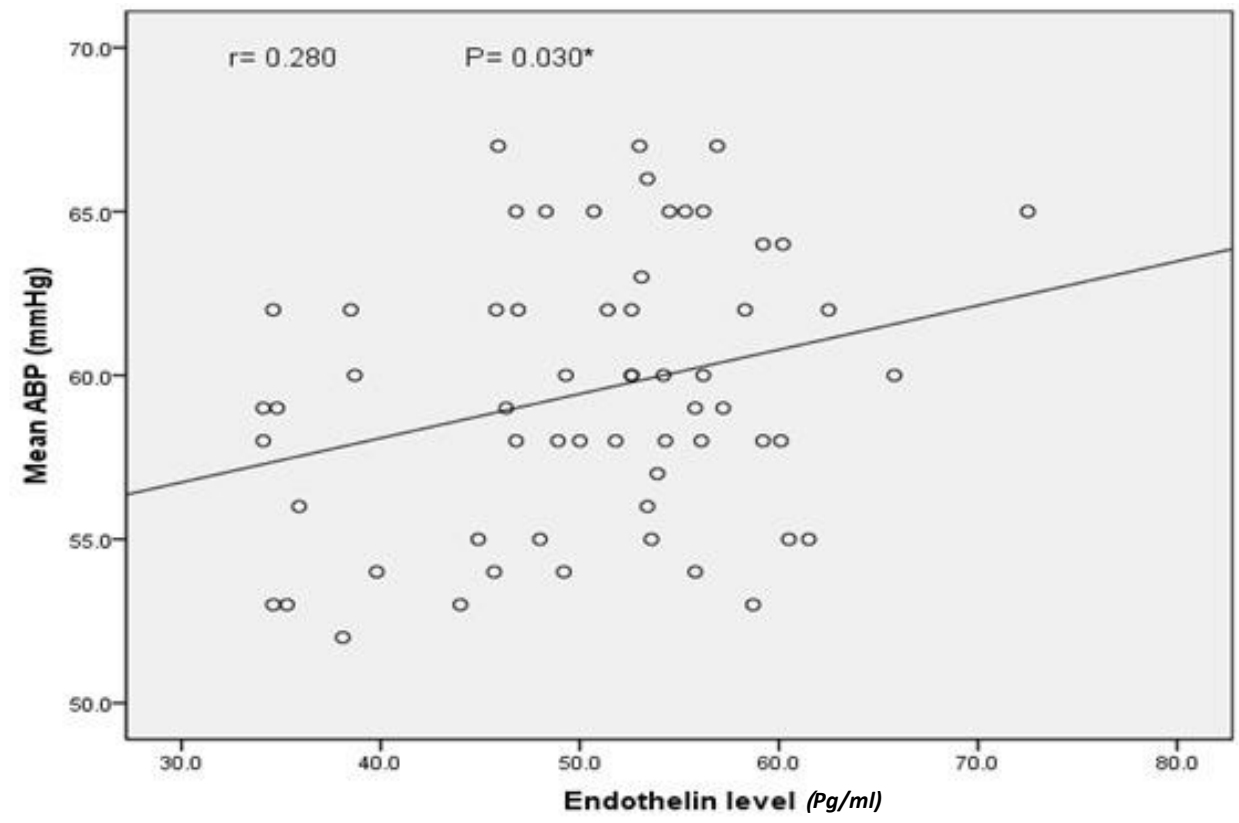

Fig. (4): Correlation coefficient between mean Endothelin levels and mean blood pressure in unconjugated hyperbilirubinemic newborn.

Fig. (4) shows positive correlation between mean Endothelin levels and mean blood pressure in unconjugated hyperbilirubinemic newborn.

\section{DISCUSSION}

The current study showed significant increase in the blood levels of both ET-1 and NO in both fullterm and preterm unconjugated hyperbilirubinemic newborns 12 hours and 24 hours after phototherapy compared to their levels before phototherapy and their controls. The study showed significant increase in serum levels of ET-1 in full term unconjugated hyperbilirubinemic newborns which was $53.20 \pm 6.14 \mathrm{pg} / \mathrm{ml}$ before phototherapy and became $55.94 \pm 6.30 \mathrm{pg} / \mathrm{ml}(\mathrm{P}$ value $=0.048)$ and $65.42 \pm 6.36 \mathrm{pg} / \mathrm{ml}(\mathrm{P}$ value $=0.013) 12$ hours and 24 
hours after phototherapy respectively, while their mean level in control was $39.27 \pm 6.37 \mathrm{pg} / \mathrm{ml}$ (P value 0.005$)$. For preterm neonates, serum ET-1 level was $47.75 \pm 9.97 \mathrm{pg} / \mathrm{ml}$ and significantly increased to $51.13 \pm 8.84 \mathrm{pg} / \mathrm{ml}(\mathrm{P}$ value $=0.046)$ and $55.31 \pm 9.30$ $\mathrm{pg} / \mathrm{ml}(\mathrm{P}$ value $=0.028) 12$ hours and 24 hours after phototherapy respectively, while ET-1 level for their controls was $31.24 \pm 5.16 \mathrm{pg} / \mathrm{ml}(\mathrm{P}$ value $=0.004)$. Regarding NO level in full term unconjugated hyperbilirubinemic newborns was $54.56 \pm 6.95$ umol/L before phototherapy and significantly increased to $59.77 \pm 5.03 \mathrm{umol} / \mathrm{L}(\mathrm{P}$ value $=0.042)$ and $62.23 \pm 5.26 \mathrm{umol} / \mathrm{L}(\mathrm{P}$ value $=0.012) 12$ hours and 24 hours after phototherpy respectively, while the level for their controls was $33.99 \pm 4.56 \mathrm{umol} / \mathrm{L}$ (P value $=0.003$ ). For preterm unconjugated hyperbilirubinemic newborns, our study showed increased serum level of NO from $41.84 \pm 7.01$ umol/L before phototherpy to $45.33 \pm 6.51(\mathrm{P}$ value $=0.048)$ and $73.13 \pm 6.36 \mathrm{umol} / \mathrm{L}$ (Pvalue $=0.012$ ) 12 hours and 24 hours after phototherapy respectively, while the level for their control was $25.62 \pm 9.8 \mathrm{umol} / \mathrm{L}(\mathrm{P}$ value $=0.014)$.

These results have led to the speculation that phototherapy induces vasodilatation via increased NO production, which led to the significant fall in MABP. The significant increase in HR may be compensatory to the fall of MABP or due to the effect of increased NO level. Another hypothesis is that NO can affect pacemaker activity leading to an increase in heart rate. Furchgott ${ }^{(9)}$ had reported that phototherapy causes vasodilation via cGMP, which might be modulated by NO.

There were many studies showing that phototherapy causes reopening of ductus arteriosus in premature infants ${ }^{(\mathbf{1 0}, \mathbf{1 1})}$. Our results are supported by study done by Youssef $\boldsymbol{e t}$ al. ${ }^{(12)}$ who reported a significant rise in both $\mathrm{NO}$ and ET-1 after phototherapy both in fullterm and preterm with no difference between fullterm and preterm. They also reported a significant correlation between each of age, heart rate and diastolic blood pressure and each of NO and ET-1, but there was no significant correlation of systolic blood pressure and both NO and ET-1 ${ }^{(\mathbf{1 2})}$.

Regarding hemodynamic changes in neonates after phototherpy, our study showed a significant rise in the heart rate in both full term and preterm unconjugated hyperbilirubinemic newborns after 24 hours of treatment with phototherpy. Moreover, a significant positive correlation was found between heart rate among term and preterm neonates after phototherapy and mean serum levels of NO and ET-1 after phototherapy $(\mathrm{r}=0.382$ and pvalue $=0.029)$ and $(\mathrm{r}=0.338$ and $\mathrm{p}$ value $=0.008)$ respectively. The heart rate was $134.50 \pm 4.73$ beat $/ \mathrm{min}$ before phototherpy and became $135.73 \pm 3.96$ beat $/ \mathrm{min}$ after 24 hours of phototherpy $(\mathrm{P}$ value $=0.05)$, while mean heart rate for their controls was $138.20 \pm 8.28$ beat $/ \mathrm{min}$ (P value $=0.038$ ). For preterm unconjugated hyperbilirubinemic newborns, their heart rate was $137.07 \pm 5.89$ beat $/ \mathrm{min}$ before phototherapy and became $140.80 \pm 5.25$ beat $/ \mathrm{min}$ after 24 hours phototherapy (P value 0.01) while heart rate for controls was $134.47 \pm 7.77$ beat $/ \mathrm{min}$. These results are supported by Uhrikova et al. ${ }^{(13)}$ who proved that there was shifted autonomic balance in icteric neonates compared to controls and also proved that mean heart rate increased in icteric neonates and further increase occured after phototherapy.

Regarding MABP in fullterm unconjugated hyperbilirubinemic newborns, it was found that there was significant decrease in MABP after 24 hours phototherapy as it was $60.30 \pm 4.42 \mathrm{mmHg}$ before phototherapy and became $57.23 \pm 4.61 \mathrm{mmHg}$ after 24 hours phototherapy $(\mathrm{P}$ value $=0.047)$ compared to their controls who were $56.37 \pm 3.90 \mathrm{mmHg}$. The MABP in preterm icteric patients was $58.70 \pm 3.82$ $\mathrm{mmHg}$ before phototherapy and became $56.37 \pm 3.55$ $\mathrm{mmHg}$ after 24-hour phototherapy $(\mathrm{P}$ value $=0.05)$ compared to their controls $53.73 \pm 3.38 \mathrm{mmHg}$.

Our study showed statistically significant positive correlation between serum ET-1 levels and $\operatorname{MABP}(\mathrm{r}=0.280$ and Pvalue $=0.030$ ) and showed statistically significant negative correlation between mean serum NO levels and MABP $(r=-0.770$ and $P$ value $=0.000$ ) among unconjugated hyperbilirubinemic newborns (full-term and preterm).

Liu et al. (8) have reported that under phototherapy blood levels of endothelin-1 and nitric oxide were significantly higher especially in preterm infant of $\leq 32$ weeks gestational age. Although, they revealed a significant decrease in MABP and a significant increase in HR in full term and preterm newborn infants. Also, Abu Faddan et al. (14) documented that phototherapy can disturb dynamic balance between NO and ET-1 leading to more prominent effect of NO of the newborns. Stec $\boldsymbol{e t}$ al. (15) stated that blood pressure decreased after phototherapy because it is proved that bilirubin is a strong antioxidant and has a protective role against angiotensin II-mediated superoxide production. This reduction in superoxide production by bilirubin is associated with increased bioavailability of nitric oxide, so reduce the effect of angiotensin II and decrease the blood pressure.

Our study showed positive correlation coefficient between mean blood nitric oxide level and total bilirubin after phototherapy $(\mathrm{r}=0.584 \quad \mathrm{P}$ value $=0.000$ ). This result is documentd by Mehmet et al. (16) who concluded that significant hyperbilirubinemia had elevated oxidative stress and disturbed antioxidant enzyme activity leading to higher blood levels of nitric oxide and there was 
positive correlation coefficient between mean blood nitric oxide levels and hemoglobin level $(\mathrm{r}=0.452 \mathrm{P}$ value 0.000). These results are supported by Rapoport et al. ${ }^{(17)}$ who reported that endogenous nitric oxide inhibits the continuous endothelin-1 mediated drive to elevate arterial blood pressure. Additionally they showed that endothelin-1 mediates a significant component of the pressure elevation by acute exposure to nitric oxide synthetase inhibitor. Thus, marked variations of endothelin-1-dependent component reflects the NO-ET1-REGULATORY pathway, and these results contradict the results obtained by by Jones and Abman ${ }^{(18)}$ who concluded that Endothelin -1 produce systemic and pulmonary hypertension in newborns due to its vasoconstrictor effect.

\section{CONCLUSION}

We concluded that an interplay was documented between mean blood levels of ET1 and NO in the form of rise of their blood levels in fullterm ad preterm unconjugated hyperbilirubinemic newborns. In addition further rise in their levels after phototherapy and their impact on hemodynamic stability appeared in form of significant decrease in MABP and significant increase of heart rate.

\section{REFERENCES}

1. Irshad M, Muhammad A, Hussain M et al. (2011): Prevalence of Rhesus type and $A B O$ incompatibility in jaundiced neonates. Journal of Postgraduate Medical Institute (Peshawar-Pakistan), 25 (3): 116-129.

2. Seidman D, Moise J, Ergaz Z et al. (2000): A new blue light-emitting phototherapy device: a prospective randomized controlled study. The Journal of Pediatrics, 136 (6): 771-774.

3. Vreman H, Wong R, Murdock J et al. (2008): Standardized bench method for evaluating the efficacy of phototherapy devices. Acta Paediatrica, 97 (3): 308-316.

4. Xiong T, Qu Y, Cambier S et al. (2011): The side effects of phototherapy for neonatal jaundice: what do we know? What should we do? European Journal of Pediatrics, 170 (10): 1247-1255.

5. Lasky R, Church M, Orlando M et al. (2012): The effects of aggressive vs. conservative phototherapy on the brainstem auditory evoked responses of extremely-low-birth-weight infants. Pediatric Research, 71 (1): 77-84.

6. Buisson A, Margaill I, Callebert J et al. (1993): Mechanisms involved in the neuroprotective activity of a nitric oxide synthase inhibitor during focal cerebral ischemia. Journal of Neurochemistry, 61 (2): 690-696.

7. Bourque $S$, Davidge $S$, Adams M (2011): The interaction between endothelin-1 and nitric oxide in the vasculature: new perspectives. American Journal of Physiology-Regulatory, Integrative and Comparative Physiology, 300 (6): 1288-1295.

8. Liu G, Wu H, Wu B et al. (2008): Effect of phototherapy on blood endothelin and nitric oxide levels: clinical significance in preterm infants. World Journal of Pediatrics, 4 (1): 31-35.

9. Furchgott $R$ (1991): Endothelium-dependent relaxation, endothelium-derived relaxing factor and photorelaxation of blood vessels. Semin Perinatol., 15: 11-15.

10. Rosenfeld W, Sadhev S, Brunot V et al. (1986): Phototherapy effect on the incidence of patent ductus arteriosus in premature infants: prevention with chest shielding. Pediatrics, 78 (1): 10-14.

11. Barefield E, Dwyer M, Cassady G (1993): Association of patent ductus arteriosus and phototherapy in infants weighing less than 1000 grams. Journal of Perinatology: Official Journal of the California Perinatal Association, 13 (5): 376.

12. Youssef D, Yousef $M$, Alshal A et al. (2018): Effect of phototherapy treatment of neonatal jaundice on blood endotherlin and nitric oxide levels: clinical significant in preterm infants. ACTA Scientific Paediatrics, 2:1-6.

13. Uhrikova Z, Zibolen M, Javorka K et al. (2015): Hyperbilirubinemia and phototherapy in newborns: effects on cardiac autonomic control. Early Human Development, 91 (6): 351-356.

14. Abu Faddan N, Abd El-Aziz N, Abd El-Azeem H et al. (2014): Effect of Phototherapy on Blood Levels of Endothelin-1 and Nitric Oxide in Hyberbilirubinemic Newborn Infants. e-Journal of Neonatology Research, 4 (1): 15-21.

15. Stec D, Hosick P, Granger J (2012): Bilirubin, renal hemodynamics, and blood pressure. Frontiers in Pharmacology, 3: 18-23.

16. Mehmet D, Ekrem G, Seref O et al. (2008): Oxidative stress and antioxidant status in neonatal hyperbilirubinemia. Saudi Med J., 29(12):1743-8.

17. Rapoport R, Draznin M, Murad F (1983): Endothelium-dependent relaxation in rat aorta may be mediated through cyclic GMP-dependent protein phosphorylation. Nature, 306 (5939): 174-176.

18. Jones O, Abman S (1994): Systemic and pulmonary hemodynamic effects of big endothelin-1 and phosphoramidon in the ovine fetus. American Journal of Physiology-Regulatory, Integrative and Comparative Physiology, 266 (3): 929-955. 